\title{
The Structure of an Arctic Microeconomy: The Traditional Sector in Community Economic Development
}

\author{
N.C. QUIGLEY ${ }^{1}$ and N.J. McBRIDE ${ }^{2}$
}

(Received 11 February 1987; accepted in revised form 17 June 1987)

\begin{abstract}
Data collected during 1984-85 are used to describe income and expenditure flows in Sanikiluaq, N.W.T. (the principal settlement on the Belcher Islands in Hudson Bay) and to construct a model that distinguishes between the traditional and modern sectors, as well as between the cash and non-cash (traditional food) sectors, of the community economy. When judged by imputed value, the harvest from the traditional sector is the single largest component of community income, but this activity necessarily has close links with the cash sector. Expansion of activity in the traditional food sector is hampered by the necessity of purchasing equipment and fuel in advance, and because there are few opportunities to sell the output of this sector, the problem cannot be solved solely by availability of credit. Because the cash income from jobs in the business and government sectors of the economy are concentrated in a small number of households, receipts from carving and social assistance play a crucial role in relieving the cash constraint on households operating primarily in the country food sector. We conclude that policies designed to ensure the vitality of the country food sector, by removing cash constraints on participation and investigating the sustainability of future harvesting levels, should be an integral part of community development strategies.
\end{abstract}

Key words: Sanikiluaq, Inuit, community economic structure, traditional food sector, income and expenditure, economic development strategies

RÉSUMÉ. On se sert de données recueillies en 1984-85 pour décrire les flux des revenus et dépenses à Sanikiluaq, le village le plus important des îles Belcher dans la baie d'Hudson (T. du N.-O.), et pour construire un modèle qui distingue entre les secteurs traditionnels et modernes, ainsi qu'entre ceux des liquidités et ceux non monétaires (alimentation traditionnelle) de l'économie de la communauté. Si l'on s'en remet à la valeur imputée, la composante la plus importante des revenus de la communauté est constituée de loin par le produit de la chasse et de la pêche du secteur traditionnel. Il est cependant évident que cette activité est associée de façon étroite au secteur des liquidités. L'obligation d'acheter à l'avance l'équipement et le combustible constitue un obstacle au développement des activités dans le secteur traditionnel de l'alimentation, et, parce qu'il existe peu d'occasions de vendre le produit de ce secteur, le problème ne peut être résolu par le seul accès au crédit. Vu que les encaissements provenant des emplois dans les secteurs économiques des affaires et du gouvernement sont concentrés dans un petit nombre de foyers, les recettes provenant de la sculpture et de l'assistance sociale jouent un rôle crucial pour alléger les contraintes monétaires dans les foyers qui travaillent surtout dans le secteur alimentaire local. On en conclut que les stratégies de développement de la communauté doivent absolument inclure des politiques visant à assurer la vitalité du secteur alimentaire local en supprimant les contraintes monétaires sur la participation, et en examinant si le niveau de production de la chasse et de la pêche pourrait être maintenu.

Mots clés: Sanikiluaq, Inuit, structure économique de la communauté, secteur traditionnel de l'alimentation, revenus et dépenses, stratégies de développement économique

Traduit pour le journal par Nésida Loyer.

\section{INTRODUCTION}

During recent years, considerable attention has been focussed on the need to stimulate economic development in the Inuit communities of the Northwest Territories. Economic development has generally implied the introduction of the business and wage labour economy to the exploitation of renewable and nonrenewable northern resources. In part, this focus reflects the desire of policymakers to raise material standards of living among native people to a level more nearly approaching that which exists in southern Canada. But such development has also been proposed because of a widely held perception of a major crisis in Inuit communities: rapid population growth has created high levels of unemployment and welfare dependence as a result of the diminishing importance of the traditional hunting and gathering sector and the failure of the wage labour sector to expand to provide alternative employment. From this point of view the problem does not lie with the demise of the traditional sector (which is regarded as inevitable, given population pressure on finite resources and the supposed inferiority of traditional lifestyles) but with the economic and cultural difficulties of stimulating business enterprises in the remote microeconomies of the North.

This view has recently attracted considerable criticism, not just because of the colonial mentality underlying it, but also because scientific research has largely refuted both the assump- tion that the traditional sector of Inuit community economies is in decline and the suggestion that this sector cannot form an important basis for future economic development plans (Brody, 1975 , 1983; Usher, 1982). Particular attention has been focussed on quantifying the value of the traditional sector, although these studies have rarely been linked to more broad-ranging investigation of community economic structure.

The purpose of this study, therefore, is to quantify the economic significance of the traditional sector of one Inuit community, and to do this in the context of an overall analysis of income and expenditure that will fully illustrate its role and importance within the economy of that community. The investigation is based on Sanikiluaq, which, with a population of 435 in 1985 , is one of the smaller and more traditional communities in the Northwest Territories.

\section{METHODOLOGY AND DATA COLLECTION}

Our conceptual organization of the Sanikiluaq economy is primarily based on the distinction between the private (business) and government sectors and the traditional sector. We recognize that the nature, methods and incentives for carving and hunting and gathering in Inuit society have changed considerably in the last century, but we use the term "traditional" to describe these activities so as to highlight their evolution from pre-European activity (as does Brody, 1983). Within the traditional sector we

\footnotetext{
${ }^{1}$ Department of Economics, Victoria University of Wellington, Private Bag, Wellington, New Zealand

${ }^{2}$ Wellington Regional Council, P.O. Box 27-242, Wellington, New Zealand

(C) The Arctic Institute of North America
} 
distinguish between the non-cash sector (food) and those activities that generate cash income (carving and some furs), so that it is possible to consider a cash economy (including the private and government sectors with part of the traditional sector) distinct from the non-cash economy. Finally, we also consider some aspects of service activities and their place in the Sanikiluaq economy, especially because of the importance that has been accorded such activities in recent discussions of changes in advanced industrial societies (Gershuny and Miles, 1983).

Data presented in this paper were collected from October 1984 to September 1985 while N.J. McBride was employed as community economic planner in Sanikiluaq, but the views expressed are those of the authors, not necessarily the community or hamlet council. Government and private sector income estimates were collected at the end of 1984 , when all community employers were asked to estimate total wages paid and disaggregate full and part-time employment. Aggregate records of government assistance payments were provided by the Department of Social Services, Government of the Northwest Territories (GNWT), but detailed records for the community were also examined to ascertain which families/individuals were receiving payments and the reasons for the benefits.

Income earned through carving sales was calculated from the daily carving payment records of the Hudson Bay Company (the Bay) and Mitiq Co-op (Co-op) stores. A lack of accurate records during the early part of 1984 required that the 12-month period from July 1984 to June 1985 be used to provide the data for this paper. No records are available on private carving sales, but we have estimated these at $\$ 20000$ in 1984.

Harvest totals for the traditional food sector in Sanikiluaq used in this paper are those estimated by the Baffin Region Inuit Harvesting Association (Pattimore, 1985). These data were collected by one of the local hunters, who consulted each household on a monthly basis from April to December 1984 and obtained a detailed account of all birds, fish and mammals taken during that period. An estimate of the harvest for the whole year was derived by Pattimore from these data, using figures gathered in previous years and in other communities as a guideline.

Local retail expenditures have been quantified using total sales figures from the Bay, Co-op and gas outlets. However, the values of other types of expenditures, both in Sanikiluaq and outside the community, had to be estimated on the basis of our observations and experience.

\section{GOVERNMENT SECTOR INCOME}

Government jobs are the main source of full-time wage employment in Sanikiluaq (Table 1), accounting for 41 fulltime, 11 part-time and two seasonal positions in 1984. The Government of the Northwest Territories employs the teachers and teaching assistants, a social worker, a field service officer, a Department of Public Works representative and housing, maintenance and clerical staff. GNWT also provides honoraria to members of committees such as the Local Education Authority and the Hunters and Trappers' Association. The municipal payroll is divided between administrative positions and community services such as garbage and sewage collection, water delivery and snow removal. The six federal government employees were the two nurses and their support staff for the nursing station and the two Royal Canadian Mounted Police (RCMP) officers assigned to the community (Table 1).

While full-time government positions do provide a substantial
TABLE 1. Sources of personal cash income in Sanikiluaq, 1984

\begin{tabular}{|c|c|c|c|c|c|}
\hline \multirow[b]{2}{*}{ Sources } & \multicolumn{4}{|c|}{ Number of jobs } & \multirow{2}{*}{$\begin{array}{c}\text { Annual earnings } \\
(\$ 000 \mathrm{~s})\end{array}$} \\
\hline & Full-time & Part-time & Other & Total & \\
\hline \multicolumn{6}{|l|}{ Public } \\
\hline Federal & 6 & 1 & - & 7 & 226 \\
\hline GNWT & 19 & 5 & - & 24 & 606 \\
\hline Municipal & 15 & 4 & 2 & 21 & 408 \\
\hline $\begin{array}{l}\text { Social } \\
\text { assistance } \\
\text { Pension }\end{array}$ & NA & NA & NA & NA & 278 \\
\hline $\begin{array}{l}\text { Pension, } \\
\text { child care } \\
\text { Miscellaneous }\end{array}$ & $\begin{array}{c}\text { NA } \\
1\end{array}$ & $\begin{array}{c}\text { NA } \\
1\end{array}$ & $\begin{array}{l}\text { NA } \\
\text { NA }\end{array}$ & $\begin{array}{l}\text { NA } \\
\text { NA }\end{array}$ & $\begin{array}{l}72 \\
70\end{array}$ \\
\hline \multicolumn{6}{|l|}{ Private } \\
\hline Retail & 11 & 1 & - & 8 & 99 \\
\hline Motel & 4 & 6 & - & 10 & 54 \\
\hline Carving $^{2}$ & NA & NA & NA & 153 & 301 \\
\hline Other $^{3}$ & 2 & NA & NA & NA & 58 \\
\hline $\begin{array}{l}\text { Traditional } \\
\text { Fur }\end{array}$ & NA & NA & NA & NA & 29 \\
\hline Total & & & & & 2201 \\
\hline
\end{tabular}

${ }^{1}$ Includes the planner position, honoraria, the Local Education Authority secretary, income estimated to have been earned by interpreters and income earned through government grants or contracts.

${ }^{2}$ Note that the carving figures are based on data gathered from the Bay and Mitiq Co-op for the one-year period July 1984-June 1985. An additional $\$ 20000$ was added to this figure as an estimate of carvings sold privately.

${ }^{3}$ Shell Canada, Air Inuit, taxi service and construction earnings.

injection of cash into Sanikiluaq, the benefits are not widely distributed within the community. Ten of the full-time positions were filled by non-Inuit persons, and their salaries amounted to $\$ 490000$, or $38 \%$ of government sector salaries. This concentration of wealth appears to be even more significant when viewed in terms of household income. These ten full-time positions were distributed among seven households containing $2.7 \%$ of the population of Sanikiluaq. It is apparent that the comparative affluence of the teachers and RCMP who make up these households is a cause for resentment among some of the unemployed and the young people in the community, quite apart from the implications this has for local economic development (discussed below).

Social assistance payments in Sanikiluaq in 1984 amounted to $\$ 278000$, or about $12.7 \%$ of total cash income in the community. This figure was slightly larger than the amount paid to the five non-native teachers at the school in Sanikiluaq, but was spread over 200 different persons, or approximately onehalf of the Inuit community. Thus, social assistance payments were allocated at the average rate of approximately $\$ 116$ per person per month, although the maximum allowable payment per person that had been set for Sanikiluaq was $\$ 132$ per month. Additional and/or occasional payments for clothing, household items and other necessities can be made at the discretion of the social worker. Requests are assessed on an individual basis and are generally only available after all other sources of funds have been exhausted. Where applications for funds are declined, the decision can be appealed by the applicant. Despite this, few funds are obtained from this source.

Given the high cost of store-bought food in Sanikiluaq, this amount would not be sufficient to provide even a substantial portion of the food requirements of an adult for one month. But the Inuit do not use social assistance as a form of basic support, since almost all of the families who collect assistance payments are still involved in the traditional hunting and gathering sector to a large degree. Thus, welfare can best be viewed as providing 
the cash needed by families whose primary source of income is country food, in the absence of a viable cash market for country food and fur products (except bear and fox pelts).

\section{PRIVATE SECTOR INCOME}

The retail trade in Sanikiluaq in 1984 was completely controlled by the Co-op and the Bay, who between them paid $\$ 99000$ in wages and salaries during the year. Both stores were run by non-Inuit managers, with the Bay also having a nonnative assistant. For other positions in the two stores, the wages paid were generally lower, part-time work was more freely available than in the government sector and necessary training was given on the job, resulting in the stores being staffed by Inuit people, generally women. Less than one-half of the wages paid out by the two stores was earned by Inuit people. Similarly, a substantial proportion of the wages paid by the Amaulik Motel (which is owned and operated by the Co-op) went to spouses of non-native people working in the community, with the rest being disbursed among a number of Inuit cleaning staff and kitchen assistants.

For several years the Sanikiluaq gas station has been run by a local entrepreneur who took the struggling business over from the Co-op. He employed one assistant and was the only successful independent Inuit business person in the community. At the end of 1984, two taxi services were started, one run by the Co-op and designed largely for motel guests, and a second run as an independent business. The latter has employed a number of people on a casual basis but has not proved to be more than marginally profitable.

\section{TRADITIONAL SECTOR INCOME}

The soapstone carving industry provides by far the most important source of non-government cash income for households in Sanikiluaq. For many Inuit, particularly those who speak little or no English, carving is the only viable means of earning the cash necessary to equip themselves for hunting. The carvers essentially act as independent business people, gathering their own supply of stone during the summer and selling completed carvings to the Co-op, the Bay or private buyers. Only one carver in Sanikiluaq is sufficiently skilled and well known that he can sell all his carvings to individuals, although many of the carvers in the community make occasional private sales. Of the carvings sold to the two stores in Sanikiluaq, the Co-op purchased $73 \%$ (by value), and wholesale carving sales provide a large component of the Co-op's income each year.

For the period July 1984-June 1985 a total of 153 people ( 82 males, 71 females) appeared in the carving purchase records of the Bay or Co-op, having sold at least one item during the 12-month period. The total recorded purchase price for these carvings was $\$ 245634.13$, with the final purchase price received by the carvers rising to $\$ 281496.71$ when an average of a $20 \%$ rebate is assumed for all carvings sold through the Co-op. The $20 \%$ additional payment to carvers arises from the discrepancy between prices assessed by the carving buyer in Sanikiluaq, and therefore initially paid to the carvers, and the price the Co-op received for the carvings from the southern distributor, Canadian Arctic Producers. On average, the prices assessed have tended to be $20 \%$ lower than the actual prices received, and the Co-op has paid this amount to the carvers at the end of each financial year.
Despite the existence of a strong market for soapstone carvings from Sanikiluaq (which has persisted while the market for the carvings of other communities has deteriorated in recent years), $63 \%$ of the carvers in Sanikiluaq earned less than $\$ 1000$ during the 12-month period examined (Table 2). There were 56 people who earned more than $\$ 1000$ for the year, and of these 36 were men and 20 were women. But even including the person who sells all his carvings privately, only 4 carvers (all male) produced a sufficiently large number of quality carvings to earn more than $\$ 10000$ for the year.

TABLE 2. Individual earnings from carving in Sanikiluaq, July 1984June 1985

\begin{tabular}{ccccc}
\hline \hline & \multicolumn{4}{c}{ Number of persons earning } \\
Age group & $<\$ 1000$ & $\$ 1000-\$ 4999$ & $\$ 5000-\$ 9999$ & $\geq \$ 10,000$ \\
\hline $5-18$ & 16 & 2 & 0 & 0 \\
$19-29$ & 26 & 4 & 0 & 0 \\
$30-40$ & 33 & 13 & 4 & 1 \\
$41-64$ & 18 & 22 & 7 & 2 \\
$65+$ & 4 & 1 & 0 & 0 \\
\hline \hline
\end{tabular}

For most of the Sanikiluaq Inuit, therefore, carving is no more than an occasional activity providing a meagre cash income. As a result, many of the households in the community that still function primarily within the traditional sector find they must supplement carving earnings with the collection of some social assistance benefits to obtain the cash income required to maintain their households. Therefore, carving, like welfare, is primarily significant for its role as a cash supplement to the country food sector.

Hunting, fishing and gathering do not provide a significant proportion of the cash income of Sanikiluaq. In the 1984-85 season, only $\$ 29050$ was received from the sale of polar bear and fox skins in the community. There was no commercial market for other types of pelts or food. But data are sufficient to provide an estimate of total wildlife harvesting by Sanikiluaq residents and, using the method for determining the imputed value of traditional foods adopted by Usher (1976) - calculating edible weight quantities and pricing these at the same rate as the nearest equivalent store-bought food - it is possible to establish a cash-equivalent value for the traditional food harvest (Table 3).

The Baffin Region Inuit Harvesting Study (Pattimore, 1985) provides an estimate of the total edible weight for each species harvested in Sanikiluaq. Average prices per kilogram for chicken, frozen fish (haddock) and various beef and pork cuts were put together from a Sanikiluaq food price survey conducted late in 1984, and these kilogram prices were applied to the fish, fowl and reindeer, seal and whale harvest numbers respectively, so that a total dollar value could be estimated on the basis of wildlife harvest figures.

We have estimated that traditional food sources harvested in 1984 by the Sanikiluaq people had an imputed value of $\$ 2.9$ million, or $\$ 7079$ per person. Seal accounts for $75 \%$ of the total value of country food obtained by the community, but significant quantities of beluga whales, Arctic char, Canada geese and eider ducks are also harvested (Table 3 ). No attempt has been made to calculate the costs incurred during the hunting and gathering process to provide a net imputed value for the country food harvest because of the extreme difficulties involved in 
TABLE 3. Calculations of imputed value of country food harvested by Sanikiluaq residents, 1984

\begin{tabular}{|c|c|c|c|c|}
\hline Species & $\begin{array}{c}\text { A } \\
\text { Estimate of } \\
\text { number } \\
\text { harvested }\end{array}$ & $\begin{array}{c}\text { B } \\
\text { Edible weight }^{1} \\
\text { per animal } \\
(\mathrm{kg})\end{array}$ & $\begin{array}{c}\text { C } \\
\text { Value } \\
\text { per } \\
\mathbf{k g}^{2}(\$)\end{array}$ & $\begin{array}{c}\mathrm{A} \times \mathrm{B} \times \mathrm{C} \\
\text { Imputed } \\
\text { value } \\
(\$)\end{array}$ \\
\hline Ringed Seal & 3020 & 59 & 11.40 & 2031252.00 \\
\hline Bearded Seal & 136 & 98 & 11.40 & 151939.20 \\
\hline Harbour Seal & 5 & 73 & 11.40 & 4161.00 \\
\hline Walrus & 15 & 185 & 11.40 & 31635.00 \\
\hline Narwhal & 2 & 496 & 11.40 & 11308.80 \\
\hline Beluga Whale & 72 & 372 & 11.40 & 305337.60 \\
\hline Polar Bear ${ }^{3}$ & 25 & 159 & NA & NA \\
\hline Arctic Hare & 7 & 2 & 7.20 & 100.80 \\
\hline \multicolumn{5}{|l|}{ Arctic Fox } \\
\hline - white ${ }^{4}$ & 178 & NA & NA & NA \\
\hline - blue & 19 & NA & NA & NA \\
\hline Red Fox & 131 & NA & NA & NA \\
\hline Reindeer 5 & 38 & 48 & 11.40 & 20793.60 \\
\hline Ptarmigan & 180 & .63 & 7.20 & 816.48 \\
\hline Snow Goose & 934 & 1.60 & 7.20 & 10759.68 \\
\hline Canada Goose & 4252 & 2.40 & 7.20 & 73474.56 \\
\hline Brant & 359 & 1.40 & 7.20 & 3618.72 \\
\hline Oldsquaw & 281 & .50 & 7.20 & 1011.60 \\
\hline Eider & 7615 & 1.50 & 7.20 & 82242.00 \\
\hline Thick-billed Murre & 51 & .70 & 7.20 & 257.04 \\
\hline Black Guillemot & 922 & .40 & 7.20 & 2655.36 \\
\hline \multicolumn{5}{|l|}{ Arctic Char } \\
\hline — anadromous & 17891 & 2 & 5.00 & 178910.00 \\
\hline - landlocked & 282 & 1 & 5.00 & 1410.00 \\
\hline Cod & 896 & 1 & 5.00 & 4480.00 \\
\hline Sculpin & 1176 & .23 & 5.00 & 1352.40 \\
\hline Total & & & & $\$ 2917515.84$ \\
\hline
\end{tabular}

'As taken from Table 16 in Pattimore (1985).

${ }^{2}$ Figures based on a food price survey undertaken in Sanikiluaq during 1984.

${ }^{3} \mathrm{An}$ imputed value was not calculated for polar bears because they are primarily

hunted for their skins and traditional significance within Inuit culture.

${ }^{4}$ As the Belcher Island fox are generally only eaten when they are fat, this species has not been included in the calculations.

${ }^{5}$ The average edible weight for caribou has been assumed for reindeer.

estimating such production costs. (For a comment on this problem see Usher, 1976.)

Although Usher has noted that in some communities the consumption of seal meat declined to a large extent in the 1970s, and that it was largely used for dog meat up to that time, seal continues to be the most important single item in the diet of the Sanikiluaq Inuit. The abundance of fish and bird life around the Islands is also evident from the harvesting figures in Table 3. Caribou have been absent from the Belcher Islands since the mid-nineteenth century, but a recently transplanted reindeer herd has thrived on the Islands and will in the future form a much more significant element of the country food harvests than it did during 1984. The Belcher Islands reindeer herd is, in fact, an important example of the types of initiatives that can promote and revitalize the country food sector in the arctic microeconomies (Ferguson, 1982).

We regard our estimate of the value of the food acquired in the traditional sector of the economy as a minimum figure. It does not include the annual collection of birds' eggs, the Sunday family outings to gather mussels, sea urchins and sea cucumbers, the collection of berries and edible plants or the value of clothes made from animal skins and down. Nor does it include the cultural and social significance of the various harvesting activities within the community and the superior nutritional value of country food.

\section{PERSONAL EXPENDITURE BY SANIKILUAQ RESIDENTS}

Expenditure at the Co-op and the Bay stores totalled $\$ 1494000$ for the 1984 fiscal year, and we have assumed that purchases by non-residents were negligible (Fig. 1). Figure 1 includes purchases of food, clothing, household goods, skidoos, boats and motors and trimodals, and it appears that these two stores handle almost all purchases in these categories made by Sanikiluaq residents. The next largest business in the community is the gas station, where $\$ 90000$ was spent in fiscal 1984 (exclusive of the fuels purchased by the government or various airline companies). In addition, we have estimated that $\$ 20000$ was spent by non-native residents of Sanikiluaq in purchasing carvings, $\$ 25000$ was spent on air tickets to travel to Great Whale River or Inoucdjouac and that spending at the amusement arcade run by the Co-op for part of the year and on the taxi might total $\$ 7000$. Some money is spent on lottery tickets, bingo and in informal gambling, but the values of these are difficult to estimate with any accuracy, and most of the money spent on these pursuits appears to stay within the community.

In contrast, the absence of any accurate data means that we can do no more than estimate the amount of personal expenditure that flowed directly to businesses outside of Sanikiluaq in 1984. It is known that money transfers through postal money orders and Bay and Co-op cash transfers of at least $\$ 309000$ occurred during 1984, with the bulk of these being transfers to relatives in other communities or payments for goods not purchased through the Bay or Co-op (e.g., mail order catalogues, vehicle purchases).

We have estimated that an additional $\$ 75000$ was spent on merchandise purchased from businesses located outside of Sanikiluaq and paid for by personal cheques (of which flows we have no record). Payments to Bell Canada for local service and personal long distance calls were estimated at $\$ 10000$. Money spent during vacations in the South or on non-business travel costs could reasonably be expected to total at least $\$ 50000$ in a community of this size and wealth.

Although the level of personal savings among the Inuit population is not known, Sanikiluaq residents who originate from southem Canada can be expected to accumulate substantial savings (either in southern bank accounts or southern property), and an estimate of $\$ 100000$ external personal savings for the non-native population alone during 1984 is not considered excessive. Expenditures aside from those listed the purchase of drugs and alcohol, for example - undoubtedly occur, but for a lack of more accurate figures they will simply be labelled "other" and an estimate of $\$ 50000$ placed on this category.

\section{A MODEL OF INCOME AND EXPENDITURE FLOWS}

As an aid to conceptualizing the relative sizes and roles of these different sectors of the Sanikiluaq economy and exploring the implications of community economic structure for development, the available data, together with our estimates on income and expenditure flows, have been combined as a basis for the simple model presented in Figure 1. The model distinguishes between sources of local income, different types of local income and flows of expenditures.

Cash incomes were predominantly generated by government departments, largely for employment rather than social assistance, but sales to external markets and local spending were also 


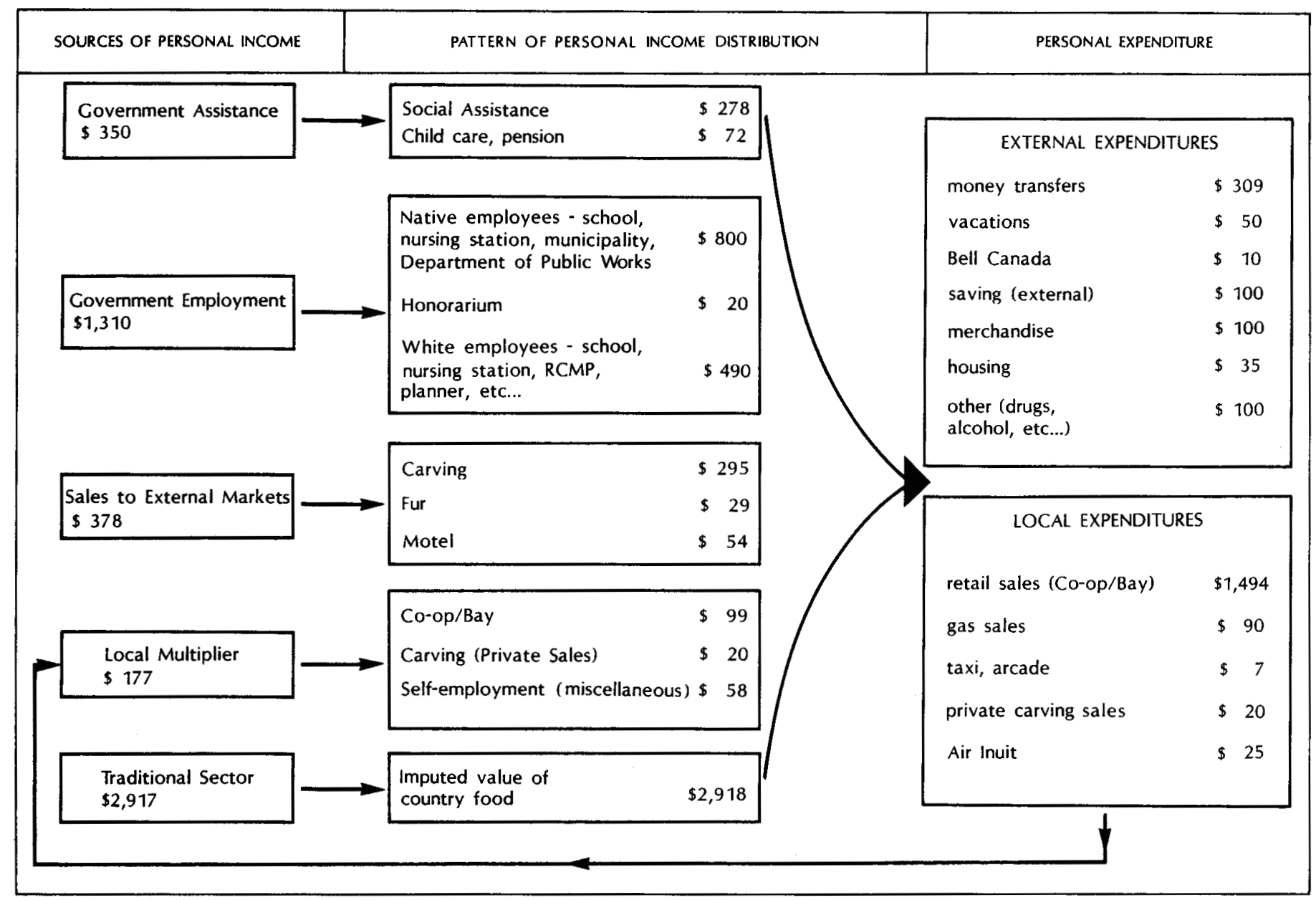

FIG. 1. Estimated personal income and expenditure in Sanikiluaq, 1984 (\$000s).

important. The cash economy made up $43 \%$ of total community income in 1984, of which social assistance $(5.4 \%)$, government employment of Inuit people (15.6\%), government employment of non-native people (9.6\%) and receipts from carving (5.7\%) provided the most significant individual components. We calculate that external and local expenditures totalled about $\$ 2184000$. While this is slightly less than cash income in the community, it is a reasonable figure, allowing for the possibility for some hoarding of cash in the community. We have assumed that local expenditures can be divided into consumer goods (by which we mean all non-productive items, such as food, clothing, furniture) and capital goods for the traditional sector (which includes rifles, ammunition, carving tools and skidoos/trimodals/boats). Both types of expenditure feed the local employment multiplier, but the purchase of capital goods also stimulates the production of carvings, furs and country food.

The country food component occupies a unique place within the economy and has a significance far beyond the fact that it provides $57 \%$ of community income. Country food can only be obtained after spending on the capital goods necessary for hunting and transportation, and while this is also true of carving, the country food sector is distinct because it provides almost no cash receipts to participants. Thus, even where credit is provided by the local stores, the absence of a cash market for country food means that this activity generates no subsequent cash expenditures and can in fact only take place where there is a transfer of funds from the cash sector to meet equipment and transportation costs.

In contrast, there can be no doubt that the cash receipts from carving are sufficient to pay for the tools purchased for the task and the cost of collecting stone, so that barriers to entering the carving sector are minimized, provided that credit is available. We therefore contend that a transfer of funds from the cash economy is necessary for the operation of the country food sector and that this transfer mechanism is the key to both the viability of an economic structure in which subsistence and cash economies coexist and the continued capacity of the country food sector to absorb large amounts of labour.

Although we have been forced to use estimates for many categories within this model where precise data were unavailable, we believe that it is a useful descriptive tool and that it presents an accurate picture of the Sanikiluaq economy. We must acknowledge that it is static and is confined to a single time period, so that the form of the model used in Figure 1 is not capable of portraying the long-run implications of changes in particular flows and types of income on the system as a whole. The model could be expanded into a dynamic format that is concerned with stocks as well as flows and that has provision for substitution between sectors over different time periods, but this would require background research and a level of formal sophistication in the construction of the model far outside the scope of this paper. 


\section{IMPLICATIONS FOR COMMUNITY ECONOMIC DEVELOPMENT}

\section{Peter Usher recently wrote:}

The fundamental question in the North today is whether the Native [traditional] mode of production must be entirely displaced, with only meaningless vestiges to remain, or whether it can be revitalized as the basis of a continuing and distinctive Native economic, social and cultural identity [1982:452].

We believe that the current importance of country food in the Sanikiluaq economy means that the continued vitality of this sector is imperative. It has the capacity to absorb relatively large amounts of labour at relatively high wage levels, provided that the long-term carrying capacity of the environment is not exceeded. Moreover, no other sector of the economy appears to hold the potential to expand employment over the next decade at the rate necessary to provide jobs for the rapidly increasing population of Sanikiluaq.

We have suggested that the most important current impediment to the expansion of the traditional food harvest is the fact that there are significant cash costs of entry to and participation in the sector, while cash incomes within the sector are negligible. This means that the availability of credit will not help overcome the constraint, since ultimately loans must be repaid. But it is apparent that an increase in the cash incomes of the Inuit people, provided that it is made available on terms that allow the recipient households to remain primarily within the traditional sector, could have a very large impact on the production of country food, and therefore on the development of the community economy as a whole. Following the model of the economy provided in Figure 1, we shall consider in turn the significance of the four main sources of cash available to Sanikiluaq residents who wish to participate in the traditional sector: social assistance payments, government employment, sales of local products to external markets and the local business/service sector, which is fueled by local spending multipliers.

Because social assistance payments in Sanikiluaq in 1984 were neither very large compared to the gross product of the community nor sufficiently generous for any individual to be completely dependent on these, any suggestion of "welfare dependence" as that term is normally understood is highly inappropriate. The true significance of social assistance payments in Sanikiluaq is that they provide a supplement to the pool of funds available to the cash-constrained families who participate in the traditional sector.

There are two problems with this situation. First, many government policymakers do not recognize that social assistance payments have this effect on the economy. As a result, they fail to understand that shortsighted policies such as largescale cutbacks in social assistance payments will, in the absence of alternative hunting subsidies, actually result in reduced participation in the traditional food sector. Second, the welfare payments are so small that they do little to aid young people to acquire the necessary start-up capital for the purchase of hunting equipment and transportation.

The GNWT Department of Renewable Resources has a variety of programs available to assist people engaged in hunting and trapping. These programs are, however, quite restrictive in terms of eligibility and usually assume that applicants will contribute a substantial portion of the funds required for this activity from their own cash resources. The slowness with which applications are processed often means that assistance is not available within a time period that makes it practical or useful for Inuit hunters to apply. These funds are administered by the Department of Renewable Resources, not by the Department of Economic Development and Tourism, a clear indication of the continued lack of recognition of the importance of the traditional economy as a basis for community development. So, while there are alternative sources of aid to hunters, these are poorly funded, relatively difficult for the Inuit people to tap and therefore insufficient to deal with this problem.

Government employment provides an important injection of cash into the Sanikiluaq economy, but its role as a facilitator of activity in the traditional sector is limited. Over $37 \%$ of government salary payments in Sanikiluaq go to non-native professionals, and only a small amount of these funds is channelled into the hands of families involved in the traditional sector through the purchase of carvings. In addition, there is little or no provision for job sharing in the government sector, so that hunting becomes difficult for those persons having a full-time job, while others who may wish to hunt are constrained by a lack of cash to purchase necessary equipment. Within households, there will doubtless be some sharing of cash income and hunting equipment. But this simply means that the cash constraint may operate on household units rather than an individual basis.

There are possibilities for the sale of more locally produced goods to external markets, and these are particularly appealing given the compatibility of activities such as carving, craft industries, tourism and hunting for furs with the country food sector. Nonetheless, these activities provide no panacea for development.

The market for Sanikiluaq soapstone carvings continues to be strong, largely because of the quality of the carvings, itself a direct result of the softness and distinctive colour of Sanikiluaq stone. However, it is unrealistic to expect that the market is sufficiently strong to bear a very large increase in output, especially if that were to lead to deterioration in the quality of the carvings. There is some potential for the Inuit communities to reduce the profits of intermediate organizations in the carving distribution network, thus increasing returns to carvers, but even if this were to happen (and as our data demonstrate), few people can carve sufficiently well to earn a substantial amount of money. There is scope for the development of other craft industries, and in particular, the current proposal to produce eider down duvets in the community seems to have potential, especially given the high local value-added component of such products. Expansion of the craft industry might stimulate tourist development, which would inject more cash into the community through direct carving sales and payments to local guides and the motel, but the high costs of transportation into Sanikiluaq, as with all arctic communities, means that tourist traffic will never be large.

Given the number of seals killed for food by the Inuit of Sanikiluaq, the emergence of a strong market for seal skins would result in a significant injection of additional cash into the Sanikiluaq economy. The skins of seals harvested in Sanikiluaq would provide a cash income of almost $\$ 80000$ to the community if each skin was worth $\$ 25$. Although the GNWT is experimenting with the use of seal to manufacture leather products (where the leather would not be so readily recognizable as seal skin), the bad publicity the seal industry in Canada has recently received means that it is difficult to foresee the emergence of such a market in the near future. Finally, there have been proposals to develop otherexportindustries from Sanikiluaq, such as the harvesting and processing of sea urchins and sea 
cucumbers, but given transportation costs to the urban areas where such products could be marketed, they would never be profitable without government subsidies far larger than warranted by the potential to generate employment (see McBride, 1985 , for a more detailed discussion).

The size of the local spending/employment multiplier is limited to a large degree by the income derived from other sectors. In addition, we have observed (but not been able to quantify) that local expenditures by non-native professionals in the community tend to be relatively small compared to the size of their cash incomes, the tendency being for these people to order in bulk from wholesalers outside the community or purchase food and goods while on trips to southern Canada, as well as to invest in southern assets such as real estate.

Nonetheless, there are two ways in which employment in the local service sector could be increased. First, sales of clothing, sporting goods and skidoos/trimodals/boats could probably each form the basis of moderately successful businesses. Such stores could attract a significant amount of business from people who currently purchase directly or through mail order catalogues from southern Canada. Any expansion of activity in the traditional food sector will have an important positive impact on the sales of retail outlets so long as the hunters are not constrained by cash shortages. But where a cash constraint does apply, the extent to which the traditional food sector has the potential to stimulate development of the service sector is severely limited. There is also scope for a restaurant, although its success will also be dependent on the size of the disposable cash income within the community.

Second, employment and cash income for the Inuit people in the community would be maximized if the business of the Bay store were acquired by the Co-op, not only because of the two jobs in the Bay store currently occupied by non-native people and the flow of profits out of the community, but also because the Co-op has a higher ratio of salaries to sales. Although a precedent for such action has recently been provided by the Kingfisher Lake Indian Band, such a move seemed unlikely in Sanikiluaq in 1985, given the lack of local control of the Co-op and local unease about the response of the Co-op manager and the Arctic Co-op organization to a monopoly position.

\section{CONCLUSION}

It is our contention, therefore, that the traditional food sector is the key element in the economic structure of Sanikiluaq and other similar arctic communities. We have argued that where a cash constraint to the development of this sector exists, it could to some degree be relieved by training Inuit people to fill the jobs currently occupied by non-native professionals, by job sharing in the government sector, and by the expansion of both the local service sector and the craft industries in these communities. But it is precisely because of the importance of the distinction between the cash and non-cash economies and the fact that over $50 \%$ of community income is generated in the latter that the potential for locally based growth in the service sector of arctic microeconomies is very restricted. Thus, our most fundamental conclusion is that the GNWT should attempt to find the funds to subsidize the traditional sector by reducing the costs of entry to the sector and the daily costs of hunters or otherwise providing injections of cash into it, by promoting research and development that will increase the productivity of the traditional sector, and by sponsoring scientific research into the long-term carrying capacities of arctic environmental systems. Present knowledge about the carrying capacities of arctic environments is extremely limited, so that research on the sustainability of different harvesting levels must form an integral part of any such development plans (Weeden, 1985).

The territorial government has recently demonstrated that it is prepared to provide very large subsidies to promote the development of both small businesses and large corporations in the Arctic. The diversion of even a small proportion of these funds into subsidies for the traditional sector holds the potential to provide very large returns on government investment, as judged by the growth of total community income, the wide distribution of that income among Inuit households and the spinoffs for the local service sector that would result.

\section{REFERENCES}

BRODY, H. 1975. The People's Land: Whites in the Eastern Arctic. Markham: Penguin. $240 \mathrm{p}$.

1983. Maps and Dreams: Indians and the British Columbia Frontier. London: Jill Norman and Hobhouse. 297 p.

FERGUSON, M. 1982. Reindeer in the Belcher Islands. Northwest Territories Wildlife Notes No. 6. 2 p.

GERSHUNY, J.I., and MILES, I.D. 1983. The New Service Economy: The Transformation of Employment in Industrial Societies. London: Frances Pinter. 281 p.

McBRIDE, N.J. 1985. Report of the Community Economic Planner for Sanikiluaq. Frobisher Bay: Department of Economic Development and Tourism. 73 p.

PATTIMORE, J. 1985. Inuit Wildlife Harvest for 1984 in the Baffin Region. Frobisher Bay: The Baffin Region Inuit Harvest Association. $10 \mathrm{p}$.

USHER, P.J. 1976. Evaluating country food in the northern native economy. Arctic 20(2):105-120.

1982. The North: Metropolitan Frontier, Native Homeland. In: McCann, L.D., ed. A Geography of Canada: Heartland and Hinterland. Scarborough: Prentice Hall. 411-456.

WEEDEN, R.B. 1985. Northern people, northern resources and the dynamics of carrying capacity. Arctic 38(2):116-120. 